\title{
Profile and Opinion of Women Farmer towards Farming as an Occupation in Tribal Setting of Uttarakhand, India
}

\author{
Ritu Shah", A.K. Singh and Manohar Saryam \\ Dept. of Extension Education, Institute of Agricultural Sciences, Banaras Hindu University, \\ Varanasi, UP, India \\ *Corresponding author
}

\section{A B S T R A C T}

\section{Keywords}

Farm women,

Farming,

Occupation,

Opinion, Tribal

Article Info

Accepted:

10 December 2018

Available Online:

10 January 2019
The present study attempts to view the profile of tribal women farmers of Uttarakhand and their opinion towards farming as an occupation. The study was purposively conducted in Uttarakhand. From the state two districts and from each district two blocks were randomly selected. From each block two villages were selected randomly. And from each village 25 respondents were randomly selected. To rank the opinion at aggregate level, Garrettt's Ranking Technique was used. The results showed that majority (46\%) of overall respondents belongs to young age category and majority $(34.50 \%)$ of the overall respondents had primary level education. Majority $(73.5 \%)$ of overall respondents had agriculture as their primary occupation. Majority of the respondents $(58.50 \%)$ were from nuclear family and majority of overall respondents $(62 \%)$ were marginal farmer having land holding less than 2.48 acre. Family occupation was ranked first by the respondents for reason of taking farming as an occupation. Majority of the respondents found that timely availability of quality seeds and other inputs was the most important step needed to enhance attractiveness of farming occupation.

\section{Introduction}

Farming as a profession provides opportunities to contribute in the mission of eradicating hunger and enabling food security. Farming has been successfully used as a tool of women empowerment in the rural settings where women are financially dependent upon men totally. According to Census 2011, India has a population of 1.21 billion. More than 800 million Indians live in rural areas and 400 million live in urban areas. Scheduled Tribes (STs) constitute 8.6 per cent of the country's population. In developing countries migration of men in search of paid employment and rising mortalities attributed to increase numbers of female-headed households which is more visible in hilly region of Uttarakhand. Both women and men play critical roles in agriculture throughout the world. Rural women in particular are responsible for half of the world's food production and produce between 60 and 80 per cent of the food in most developing countries. Despite their contribution to global food security, women farmers are frequently underestimated and sidelined in development strategies (FAO, 2011). Farm Women is an integral part of the 
human society. Women contribute one third labour force required for farming operations and allied enterprises. They have been playing significant role in Home, farm and Allied activities. In Indian context farming is a family occupation. They play a variety of roles with greater responsibilities in upbringing of a healthy society. They play active role in supporting their households and communities in achieving food and nutrition security, generating income, and improving rural livelihoods and overall well-being. They also contribute to agriculture and rural enterprises and local and global economies. Active participation of women in the entire development process is essential for the overall socio-economic development of any country. Therefore, raising the status of women in general and that of socially and economically backward women in particular is not just a moral imperative but also a strategic one. In Uttarakhand the work force engaged in agricultural activities is $58.39 \%$ of total work force. The share of female work force in total work force is $36.31 \%$. The occupational distribution (2001 census) indicates that the share of cultivators is predominant in occupational structure. In India work participation of tribal women is the highest and even better than the participation of men. Work participation rate of tribal women is 43.5, whereas national average (for general population) is 25.5 . Though the overall work participation rate decreased from 25.6 to 25.5, it is increased in urban areas. So given the feminization era of agriculture and even more prominent role of women, especially in tribal communities where women is providing livelihood support to family by increasingly getting involved in farming related activities often by choice and often as a sole option, it is crucial to undertake an intensive study to look into their perspective. Given the diversity of tribal communities living in Himalayan hill and most intensive participation of women in agriculture and allied sector in hilly region a study on tribal women farmer has been conducted.

\section{Materials and Methods}

The study was conducted in Chamoli and Dehradun districts of Uttarakhand. The data was collected from a sample of 200 tribal farm women 100 from each tribe i.e. Bhotiya (Chamoli) and Jaunsari (Dehradun). In the present study opinion has been operationalized as opinion towards reason for choosing farming as an occupation, Steps needed to enhance attractiveness in this occupation, Farming as a tool of women empowerment, Reasons behind desire to undertake other occupation, Difficulties faced in practicing farming as a women and social acceptance of being a women farmer in respective community other occupation from farm and non-farm. A set of open ended questions were prepared in order to find the opinion of respondents. Information regarding the opinion by the farm women was procured and respondents were asked to rank them. To rank the opinion at aggregate level, Garrettt's Ranking Technique was used. The prime advantage of this technique over simple frequency distribution is that the opinions are arranged based on their priority from the point of view of respondents. Hence, the same number of respondents on two or more opinion may have been given different rank. Garrettt's formula for converting ranks into per cent is:

Per cent position $=100 *\left(\mathrm{R}_{\mathrm{ij}}-0.5\right) / \mathrm{N}_{\mathrm{j}}$

Where,

$\mathrm{R}_{\mathrm{ij}}=$ rank given for $\mathrm{i}^{\text {th }}$ constraint by $\mathrm{j}^{\text {th }}$ individual;

$\mathrm{N}_{\mathrm{j}}=$ number of constraint ranked by $\mathrm{j}^{\text {th }}$ individual.

The per cent position of each rank was converted into scores referring to the table 
given by Garrettt and Woodworth (1969). For each factor, the scores of individual respondents were added together and divided by the total number of the respondents for whom scores were added. These mean scores for all the constraints were arranged in descending order; the opinions were accordingly ranked.

\section{Results and Discussion}

A perusal of the Table 1 indicate that majority (46\%) of overall respondents belongs to young age category followed by middle aged $(31 \%)$ and old aged $(23 \%)$. Majority $(51 \%)$ of respondents from Bhotiya tribe and 41 per cent from Jaunsari tribe belongs to young age followed by middle and old aged.

Data regarding education shows that majority $(34.50 \%)$ of the overall respondents had primary level education followed by middle level $(22 \%)$, illiterate $(15.50 \%)$, intermediate level (14.50\%) and high school level (13.50 $\%)$ education respectively. In both the tribe maximum number of respondents had primary level education i.e. in Bhotiya (28\%) and in Jaunsari (41\%). In Bhotiya tribe primary level education was followed by Intermediate (26 $\%)$, High school (17\%), Middle level (15\%) and Illiterate (14\%). In Jaunsari tribe primary level of education was followed by middle level (29\%), illiterate (17\%), high school (10 $\%)$ and intermediate $(03 \%)$.

A cursory look at the Table 1 also reveals that majority $(73.5 \%)$ of overall respondents had agriculture as their primary occupation followed by handicraft $(26.50 \%)$. In Bhotiya tribe majority of respondents had handicraft as their primary occupation followed by agriculture $(47 \%)$ whereas in Jaunsari tribe all the respondents had one occupation i.e. agriculture. Table also shows that majority $(26.5 \%)$ of respondents had agriculture as their secondary occupation and that too belongs to only Bhotiya tribe ( $53 \%$ ) followed by handicraft $(47 \%)$. Data regarding family type of respondents presented in the table shows that majority of the respondents $(58.50$ $\%$ ) were from nuclear family and 41.50 per cent respondent belonged to joint family. In both the tribe i.e. Bhotiya and Jaunsari, majority of respondents (66\% and $51 \%$ ) were having nuclear family type followed by respondent who had joint family (34\% and 49 $\%)$ respectively.

The perusal of table reveals that majority of overall respondents $(61 \%)$ had small size of family followed by the respondents who had medium size of family (34\%) and respondents who had large family size (05\%). In Bhotiya tribe majority of respondents $(72 \%)$ had small size of family followed by medium size of family $(28 \%)$ while in Jaunsari tribe half of the respondents $(50 \%)$ had small size of family followed by medium size of family (40 $\%)$ and large size of family (10\%).

A cursory look on the Table 1 shows that majority of overall respondents $(62 \%)$ were marginal farmer having land holding less than 2.48 acre followed by small farmers (21\%) who were having landholding between 2.48 to 4.67 acre and large farmer (17\%). In Bhotiya tribe all the respondents were marginal farmers $(100 \%)$ while in Jaunsari tribe maximum respondents $(42 \%)$ were small farmers followed by large farmers (34\%) and marginal farmers $(24 \%)$. In Bhotiya tribe no farmer was found in the category of small and large farmer. The farmers in the area had been mostly marginal farmers. The average size of land holding had been found to be $21.00 \mathrm{Nali}$ $(1$ acres $=20$ Nali). This land was not concentrated at one place but in the form of small undulated plots dispersed in different areas.

Data regarding possession of livestock by respondent's shows that majority of the respondents $(68 \%)$ had small size of livestock 
followed by 19.50 per cent respondents who were having medium size of livestock. Rest 12.50 per cent respondents possessed large size of livestock. In Bhotiya tribe all the respondents have small size of livestock while in Jaunsari tribe maximum respondents (39 \%) were having medium size of livestock followed by the respondents $(36 \%)$ who were having small size of livestock and the respondents $(25 \%)$ who were having high size of livestock.

In Bhotiya tribe they have a culture of migration. They live for six months in two valleys of Uttarakhand i.e. Niti and Mana from April to October and then from October to March some other areas where they also have their permanent house in Chamoli district. So, that is the reason they were having less size of livestock. Jaunsari tribe is totally into agriculture and majority of respondents having medium size of livestock.

Data regarding farming experience in shows that maximum number of overall respondents (48 \%) had low farming experience followed by the respondents $(33.50 \%)$ who had medium farming experience and respondents $(18.50 \%)$ who had high farming experience. In both the tribes majority of respondents (Bhotiya: $54 \%$ and Jaunsari: $42 \%$ ) had low farming experience followed by respondents who had medium farming experience and respondents who were having high farming experience.

Extension agency contact is referred to as the frequency of meeting of the beneficiary with extension personnel of various development Data regarding contact of respondents with extension agency has been presented in Table 1. Table shows that majority $(57.50 \%)$ of the respondents were having contact with the extension agency remaining 42.50 per cent were not having any contact with the extension agency. departments.
A perusal of Table 1 reveals that most of the respondents $(37.50 \%)$ had Rice-Wheat and Fingermillet/Horse gram (Gahat)-Pea-Potato cropping pattern followed by the respondents (25\%) who were having Rice-Potato-Wheat cropping pattern. 20 per cent respondents had Rajma/Horse gram (Gahat)-Wheat cropping pattern and rest 17.50 per cent respondents had Paddy/Maize-Potato/Oilseed (Mustard)Wheat cropping pattern. In Bhotiya tribe most of the respondents $(40 \%)$ had Fingermillet/Horse gram (Gahat)-Pea-Potato cropping pattern followed by respondents (35 $\%$ ) who had Rice-Wheat cropping pattern and respondents (20 \%) who followed RicePotato-Wheat cropping pattern. 15 per cent were having Rajma/Horse gram(Gahat)-Wheat cropping pattern and rest 10 per cent were having Paddy/Maize-Potato/Oilseed (Mustard)-Wheat cropping pattern. In Jaunsari tribe most of the respondents (40\%) had RiceWheat cropping pattern followed by respondents (35\%) who had Fingermillet/ Horse gram (Gahat)-Pea-Potato cropping pattern and respondents (30\%) who followed Rice-Potato-Wheat cropping pattern. 25 per cent were having Rajma/Horse gram (Gahat)-Wheat and Paddy/MaizePotato/Oilseed(Mustard)-Wheat cropping pattern.

Data regarding migration pattern depicts that majority of overall respondents $(72.50 \%)$ who do not migrate and in which 45 per cent were from Bhotiya tribe while all the respondents (100 \%) from Jaunsari tribe. Rest 27.5 per cent respondents migrate and all belong to Bhotiya tribe only. In Bhotiya tribe they have a culture of migration. They live for six months in villages of two valleys of Uttarakhand i.e. Niti and Mana from April to October where they perform farming and sell handicraft products and then from October to March some other areas in Chamoli district where they prepare handicraft products mainly. 
Table.1 Profile of women farmer in tribal setting of Uttarakhand

\begin{tabular}{|c|c|c|c|c|c|c|}
\hline \multirow[t]{2}{*}{ S.N } & \multirow[t]{2}{*}{ Variable. } & \multirow[t]{2}{*}{ Category } & \multirow{2}{*}{$\begin{array}{c}\text { Bhotiya } \\
(\mathrm{n} 1=100) \\
\text { Percentage }\end{array}$} & \multirow{2}{*}{$\begin{array}{c}\text { Jaunsari } \\
\text { (n2=100) } \\
\text { Percentage }\end{array}$} & \multicolumn{2}{|c|}{ Overall $(n=n 1+n 2)$} \\
\hline & & & & & Frequency & Percentage \\
\hline \multirow[t]{4}{*}{1.} & \multirow{4}{*}{$\begin{array}{c}\text { Age } \\
\text { (Years) }\end{array}$} & Young $(<40.52)$ & 51 & 41 & 92 & 46 \\
\hline & & $\begin{array}{l}\text { Middle (40.52.- } \\
54.69)\end{array}$ & 31 & 31 & 62 & 31 \\
\hline & & Old (>54.69) & 18 & 28 & 46 & 23 \\
\hline & & Total & 100 & 100 & 200 & 100 \\
\hline \multirow[t]{6}{*}{2.} & \multirow[t]{6}{*}{ Education } & Illiterate & 14 & 17 & 31 & 15.5 \\
\hline & & Primary & 28 & 41 & 69 & 34.5 \\
\hline & & Middle & 15 & 29 & 44 & 22 \\
\hline & & High School & 17 & 10 & 27 & 13.5 \\
\hline & & Intermediate & 26 & 03 & 29 & 14.5 \\
\hline & & Total & 100 & 100 & 200 & 100 \\
\hline \multirow[t]{9}{*}{3.} & \multirow[t]{9}{*}{ Occupation } & Primary Occupation & & & & \\
\hline & & Agriculture & 47 & 100 & 147 & 73.5 \\
\hline & & Handicraft & 53 & 00 & 53 & 26.5 \\
\hline & & Total & 100 & 100 & 200 & 100 \\
\hline & & $\begin{array}{l}\text { Secondary } \\
\text { Occupation }\end{array}$ & & & & \\
\hline & & Handicraft & 53 & 00 & 53 & 23.5 \\
\hline & & Agriculture & 47 & 00 & 47 & 26.5 \\
\hline & & Not any other & 00 & 100 & 100 & 50 \\
\hline & & Total & 100 & 100 & 200 & 100 \\
\hline \multirow[t]{3}{*}{4} & \multirow{3}{*}{$\begin{array}{l}\text { Type of } \\
\text { family }\end{array}$} & Nuclear & 66 & 51 & 117 & 58.5 \\
\hline & & Joint & 34 & 49 & 83 & 41.5 \\
\hline & & Total & 100 & 100 & 200 & 100 \\
\hline \multirow[t]{4}{*}{5.} & \multirow{4}{*}{$\begin{array}{l}\text { Size of } \\
\text { family }\end{array}$} & Small $(<9)$ & 72 & 50 & 138 & 69 \\
\hline & & Medium (9-13) & 28 & 40 & 52 & 26 \\
\hline & & Large (>13) & 00 & 10 & 10 & 05 \\
\hline & & Total & 100 & 100 & 200 & 100 \\
\hline \multirow[t]{4}{*}{6.} & \multirow{4}{*}{$\begin{array}{l}\text { Land } \\
\text { holding } \\
\text { (Acres) }\end{array}$} & $\begin{array}{l}\text { Marginal farmer } \\
(<2.48)\end{array}$ & 100 & 24 & 124 & 62 \\
\hline & & $\begin{array}{l}\text { Small farmer }(2.48- \\
4.67)\end{array}$ & 00 & 42 & 42 & 21 \\
\hline & & Large farmer $(>4.67)$ & 00 & 34 & 34 & 17 \\
\hline & & Total & 100 & 100 & 200 & 100 \\
\hline \multirow[t]{4}{*}{9.} & \multirow{4}{*}{$\begin{array}{l}\text { Size of } \\
\text { livestock }\end{array}$} & Small $(<25)$ & 100 & 36 & 136 & 68 \\
\hline & & Medium (25-43) & 00 & 39 & 39 & 19.5 \\
\hline & & Large $(>43)$ & 00 & 25 & 25 & 12.5 \\
\hline & & Total & 100 & 100 & 200 & 100 \\
\hline 10. & Farming & Low $(<22.42)$ & 54 & 42 & 96 & 48 \\
\hline
\end{tabular}




\begin{tabular}{|c|c|c|c|c|c|c|}
\hline & experience & $\begin{array}{l}\text { Medium (22.42- } \\
32.55)\end{array}$ & 34 & 33 & 67 & 33.5 \\
\hline & & High $(>32.55)$ & 12 & 25 & 37 & 18.5 \\
\hline & & Total & 100 & 100 & 200 & 100 \\
\hline \multirow[t]{3}{*}{11.} & \multirow{3}{*}{$\begin{array}{l}\text { Extension } \\
\text { agency } \\
\text { contact }\end{array}$} & Yes & 18 & 67 & 85 & 42.5 \\
\hline & & No & 82 & 33 & 115 & 57.5 \\
\hline & & Total & 100 & 100 & 200 & 100 \\
\hline \multirow[t]{5}{*}{13.} & \multirow{5}{*}{$\begin{array}{l}\text { Cropping } \\
\text { pattern }\end{array}$} & Rice-Wheat & 35 & 40 & 75 & 37.5 \\
\hline & & Rice-Potato-Wheat & 20 & 30 & 50 & 25 \\
\hline & & $\begin{array}{c}\text { Rajma/Horse } \\
\text { gram(Gahat)-Wheat }\end{array}$ & 15 & 25 & 40 & 20 \\
\hline & & $\begin{array}{l}\text { Paddy/Maize- } \\
\text { Potato/Oilseed(Musta } \\
\text { rd)-Wheat }\end{array}$ & 10 & 25 & 35 & 17.5 \\
\hline & & $\begin{array}{l}\text { Fingermillet/Horse } \\
\text { gram(Gahat)-Pea- } \\
\text { Potato }\end{array}$ & 40 & 35 & 75 & 37.5 \\
\hline \multirow[t]{3}{*}{14.} & \multirow{3}{*}{$\begin{array}{l}\text { Migration } \\
\text { pattern }\end{array}$} & Within district & 55 & 00 & 55 & 27.5 \\
\hline & & Do not migrate & 45 & 100 & 145 & 72.5 \\
\hline & & Total & 100 & 100 & 200 & 100 \\
\hline
\end{tabular}

Table.2 Reasons behind taking up farming as occupation $(\mathrm{n}=200)$

\begin{tabular}{|c|c|c|c|}
\hline S.N & Factors & Garrett Score & Rank \\
\hline $\mathbf{1}$ & Family occupation & 68.075 & I \\
\hline $\mathbf{2}$ & There is no other occupation & 61.46 & II \\
\hline $\mathbf{3}$ & Required low initial investment & 47.195 & III \\
\hline $\mathbf{4}$ & Required no educational qualification & 45.21 & IV \\
\hline $\mathbf{5}$ & It is a profitable venture & 27.12 & V \\
\hline
\end{tabular}

Table.3 Steps needed to enhance attractiveness of this occupation $(n=200)$

\begin{tabular}{|c|c|c|c|}
\hline S.N & Factors & Garrett Score & Rank \\
\hline $\mathbf{1}$ & $\begin{array}{c}\text { Timely availability of quality seeds and other } \\
\text { inputs }\end{array}$ & 65.15 & I \\
\hline $\mathbf{2}$ & $\begin{array}{c}\text { Improving access to credit, technology and } \\
\text { markets }\end{array}$ & 64.80 & II \\
\hline $\mathbf{3}$ & Improving access to modern technology & 52.72 & III \\
\hline $\mathbf{4}$ & Reduce drudgery by using women friendly tool & 36.38 & IV \\
\hline $\mathbf{5}$ & Promote organic farming/ high value crop etc & 30.15 & V \\
\hline
\end{tabular}


Table.4 Farming as a tool of women empowerment $(\mathrm{n}=200)$

\begin{tabular}{|c|c|c|c|}
\hline S.N & Factors & Garrett Score & Rank \\
\hline $\mathbf{1}$ & A source of income for the family & 68.60 & I \\
\hline $\mathbf{2}$ & An identity of being a woman farmer & 56.34 & II \\
\hline $\mathbf{3}$ & $\begin{array}{c}\text { Recognition of traditional/indigenous knowledge of } \\
\text { women by documentation, validation and dissemination }\end{array}$ & 44.32 & III \\
\hline $\mathbf{4}$ & $\begin{array}{c}\text { The stereo-typed attitude of male extension agents should } \\
\text { be changed with regular gender sensitization courses }\end{array}$ & 31.93 & IV \\
\hline
\end{tabular}

Table.5 Reasons behind desire to undertake other occupation ( $\mathrm{n}=200)$

\begin{tabular}{|c|c|c|c|}
\hline S.N & Factors & Garrett Score & Rank \\
\hline $\mathbf{1}$ & Farming do not provide a regular source of & 65.275 & I \\
\hline $\mathbf{2}$ & income & 63.675 & II \\
\hline $\mathbf{3}$ & Not getting desired income from farming & 49.615 & III \\
\hline $\mathbf{4}$ & High uncertainty in return/ high risk venture & 39.565 & IV \\
\hline $\mathbf{5}$ & Not getting buyers on time & 30.72 & V \\
\hline
\end{tabular}

Table.6 Difficulties faced in practicing farming as a woman and social acceptance of being a women farmer in respective community $(n=200)$

\begin{tabular}{|c|c|c|c|}
\hline S.N & Factors & Garrett Score & Rank \\
\hline $\mathbf{1}$ & Work overload due to multiple roles of women & 70.8 & I \\
\hline $\mathbf{2}$ & Faced health problems due to drudgery in farming & 62.4 & II \\
\hline $\mathbf{3}$ & Lack of ownership and control over the land & 44.39 & III \\
\hline $\mathbf{4}$ & Unequal wage in agriculture labour & 38.84 & IV \\
\hline $\mathbf{5}$ & Access to resources is less than their male & 32.24 & V \\
\hline
\end{tabular}

\section{Opinion towards farming as an occupation}

It has been operationalized as opinion towards reason for choosing farming as an occupation, Steps needed to enhance attractiveness in this occupation, Farming as a tool of women empowerment, Reasons behind desire to undertake other occupation, Difficulties faced in practicing farming as a women and social acceptance of being a women farmer in respective community other occupation from farm and non-farm. A set of open ended questions were prepared and asked in order to find the opinion of respondents.

\section{Reasons behind taking up farming as occupation}

Respondents were asked to rank various reasons behind taking up farming as an occupation on the basis of their farming experiences. Family occupation was ranked first by the respondents with garrett score 68.075 followed by the reason that there is no 
other occupation with garrett score 61.46. Required low initial investment was ranked third by respondents with garrett score 47.195 followed by required no educational qualification with garrett score 45.21. Reason that farming is a profitable venture was ranked fifth by respondents with garrett score 27.12 (Table 2).

Steps needed to enhance attractiveness of this occupation $(n=200)$

Majority of the respondents found that timely availability of quality seeds and other inputs was the most important step and ranked first with garrett score 65.15 followed by improving access to credit, technology and markets with garrett score 64.80. Third rank was given to improving access to modern technology with garrett score 52.72 followed by reduce drudgery by using women friendly tool with rank four and garrett score 36.38. Promote organic farming/high value crop etc. was ranked fifth with garrett score 30.15 for the steps needed to enhance attractiveness of farming occupation (Table 3).

\section{Farming as a tool of women empowerment}

Respondents were asked to rank opinion on farming as a tool of women empowerment. A cursory look of Table 4 reveals that A source of income for the family was ranked first by respondents with garrett score 68.60 followed by An identity of being a women farmer as second rank with garrett score 56.34.

Recognition of traditional/indigenous knowledge of women by documentation, validation and dissemination was ranked third by respondents with garrett score 44.32 followed by The stereo-typed attitude of male extension agents should be changed with regular gender sensitization courses with garrett score 31.93 .

\section{Reasons behind desire to undertake other occupation}

Respondents were asked to rank various reasons behind desire to undertake other occupation. Farming do not provide a regular source of income was ranked first by the respondents with garrett score 65.275 followed by the reason that Not getting desired income from farming with garrett score 63.675 (Table 5).

High uncertainty in return/ high risk venture was ranked third by respondents with garrett score 49.615 followed by Not getting buyers on time with garrett score 39.565. Reason that Agriculture is highly drudgery full job was ranked fifth by respondents with garrett score 30.72 .

\section{Difficulties faced in practicing farming as a women and social acceptance of being a women farmer in respective community}

Respondents were asked to rank opinion on Difficulties faced in practicing farming as a women and social acceptance of being a women farmer in respective community. A perusal of Table 6 shows that Work overload due to multiple roles of women was ranked first by respondents with garrett score 70.80 followed by Faced health problems due to drudgery in farming as second rank with garrett score 62.40. Lack of ownership and control over the land was ranked third by respondents with garrett score 44.39 followed by Unequal wage in agriculture labour with garrett score 38.84. Reason that Access to resources is less than their male counterparts was ranked fifth by respondents with garrett score 32.24

It could be concluded that Agriculture was the primary occupation whereas handicraft was the secondary occupation only in Bhotiya tribe. Education level was poor and 
respondents were generally involved themselves in agriculture. Respondents of both the tribe had pucca house and had all the essential facilities required. According to them they were in farming occupation majorly because it was a family occupation. These days male migration is very prominent in the villages of hilly areas specially so to make farming occupation attractive there should be timely availability of good quality seeds and all the inputs required for farming. Women farmer were facing so many difficulties as they have too much workload because of multiple role at house and field. Farming does not provide a regular source of income was the main reason behind taking up other occupation than farming. Farming is source of income for the family which makes women feel empowered.

\section{References}

Chandra A., Kandari L.S., Negi, V.S., Maikhuri, R.K. and Rao, K.S. (2009) Role of Rural and Tribal Women in Conservation of Village Ecosystem: A
Case Study of Nanda Devi Biosphere Reserve, India, Environment $\mathrm{u}$ and We: An International Journal of Science and Technology, Vol. 4.

FAO (2011). http://www.fao.org/docrep/ 013/am307e/am307e00.pdf

Ferrington, J. and Martin, A. (1988) Farmers participation in agriculture research: a review of concept and practices, Agricultural Administration unit occasional paper 9, London: ODI.

John Christy, R., (2014) Garrettt's Ranking Analysis of Various Clinical Bovine Mastitis Control Constraints in Villupuram District of Tamil Nadu, IOSR Journal of Agriculture and Veterinary Science (IOSR-JAVS) 7(4), 62-64

Kowsalya, K.S., K.C. Lalitha, Preethi and Tanweer Ahmed. (2017) Impact of Demographic Characteristics on Attitude of Farm Women towards Value Added Products of Ragi. Int.J.Curr.Microbiol.App.Sci. 6(3): 1188-1194.

\section{How to cite this article:}

Ritu Shah, A.K. Singh and Manohar Saryam. 2019. Profile and Opinion of Women Farmer towards Farming as an Occupation in Tribal Setting of Uttarakhand India. Int.J.Curr.Microbiol.App.Sci. 8(01): 1384-1392. doi: https://doi.org/10.20546/ijcmas.2019.801.147 